\title{
Azonnali emlőrekonstrukció endoszkóposan asszisztált latissimus dorsi izomlebennyel
}

\author{
Breast reconstruction surgery with endoscopic assisted \\ latissimus dorsi muscle flap
}

\author{
BOGNÁR GÁBOR ${ }^{\circledR}$, NOVÁK ANDRÁS, LEDNICZKY GYÖRGY, ISTVÁN GÁBOR
}

Semmelweis Egyetem, II. Sz. Sebészeti Klinika (igazgató: Dr. István Gábor)

\begin{abstract}
Az emlő-helyreállító műtétek eredményei a betegek számára nem mindig kielégítőek. A latissimus dorsi izomlebennyel végzett helyreállító mütét megfelelő lehetőség, és endoszkópos preparálás mellett a háti heg is elkerülhető. A hónaljban ejtett egyetlen metszésen keresztül a bőrmegtartó mastectomia és a sentinelnyirokcsomó-eltávolítás vagy az axillaris lymphadenectomia is elvégezhető. Az azonnali emlőrekonstrukcióhoz egyes esetekben a latissimus dorsi izomlebeny használható fel, amely endoszkóposan asszisztáltan ebből a metszésből kipreparálható. A bemutatott beteg az esztétikai és a funkcionális eredménnyel is elégedett volt, a mell alakjának megőrzése és a háti heg mellőzésének köszönhetően.
\end{abstract}

Kulcsszavak: emlőrekonstrukció, latissimus dorsi izomlebeny, endoszkópos sebészet, emlőrák

\begin{abstract}
The results obtaining with breast reconstruction surgery are not always satisfactory for the patients. Reconstruction with pure latissimus dorsi flap is useful option and due to endoscopic harvest large scar on the back can be avoided. The skin sparing mastectomy and even the sentinel lymph node biopsy or lymphadenectomy can be performed using a single incision in the axilla. Also the immediate reconstruction with endoscopically assisted harvest of the latissimus dorsi muscle flap in selective cases can be done using the same incision. The patient reported high satisfaction with the aesthetic and functional results due to preservation the breast shape and the absence of any scarring on the back.
\end{abstract}

Keywords: breast reconstruction, latissimus dorsi muscle flap, endoscopic surgery, breast cancer

Beérkezett: 2017. március 3.; elfogadva: 2017. április 26.

Rövidítések: DCIS - ductal carcinoma in situ, DIEP - deep inferior epigastric artery, IDC - Invasive Ductal Cancer, LAT - latissimus dorsi, NPI - Nottingham Prognostic Index, OE - oestrogén receptor, TNM - Classification of malignant tumours, TRAM - Transversal Abdominal Rectus Muscle

\section{Bevezetés}

A latissimus dorsi izomlebeny endoszkópos preparálását már 1994-ben Fine és munkatársai publikálták, ${ }^{1}$ ám emlörekonstrukciónál való alkalmazásáról csak 2000-ben írtak. ${ }^{2}$ Ezt követően is csak kevés publikáció számolt be erröl a technikáról. A legnagyobb esetszámú közlemények parciális mastectomiát követő azonnali rekonstrukciókról számoltak be. ${ }^{3-5}$ Börmegtartó (skin sparing) mastectomiák esetében végzett azonnali emlörekonstrukciókról 8-52 beteg esetében számoltak be, de egyik esetben sem voltak képek a klinikai eredményröl..$^{6-8}$ A latissimus dorsi izomlebeny endoszkópos preparálása nem elterjedt sebészeti módszer a mellkasfal görbülete és a korlátozott vizualizáció, valamint a hosszabb mütéti idő miatt. ${ }^{9}$ Menke és munkatársai csak két esetben végeztek endoszkópos preparálást 121, latissimus dorsi izomlebennyel végzett rekonstrukciós mütét kapcsán. ${ }^{10}$

A betegek, akik bőrmegtartó mastectomián esnek át, növekvő igényt mutatnak kisebb posztoperatív komplikációs eséllyel végzett és kevesebb mütét utáni ápolást igénylő rekonstruktív beavatkozásra. Ezek a betegek általában fiatalok, vékonyak és a hasi zsírszövet mennyisége nem elegendő haránt irányú rectus abdominis (TRAM) musculocutan lebennyel vagy akár a mikrosebészeti technikával végzett DIEP-lebennyel történő rekonstrukcióra. Más esetben a

\footnotetext{
${ }^{\circledR}$ Levelezési cim/Corr. address: Dr. Bognár Gábor, Semmelweis Egyetem, II. Sz. Sebészeti Klinika, 1125 Budapest, Kútvölgyi út 4. Tel.: 361325 1100; Fax: 361375 4291; E-mail: bgabor68@gmail.com
} 
beteg elutasítja a nagy morbiditással járó TRAM-lebennyel végzett rekonstrukciót, vagy a dohányzás miatt nem alkalmas rá, illetve nem akar nagy hegeket.

\section{Esetismertetés}

Fiatal, nem dohányzó, társbetegség nélküli, kisméretű emlőjü nőbetegünknél (1. ábra) hisztológiailag igazolt malignus daganatot diagnosztizáltak a bal oldali emlő belső kvadránsai határán, amely a bőrt nem érintette, ultrahanggal mérve a bőr alatt $16 \mathrm{~mm}$-re helyezkedett el, távolsága az areolától több mint $2 \mathrm{~cm}$ és mérete kisebb volt, mint $3 \mathrm{~cm}$, így subcutan mastectomiát végeztünk a bőr és a mellbimbó megtartásával (nipple spearing mastectomy). A tumor (hisztológia: IDC + DCIS: $28 \times 19 \mathrm{~mm}$, TNM: T2N1Mx, Gr. III, NPI: 4,054, OE: pozitív, PR: pozitív, Her-2: negatív, 2/8 nyirokcsomó pozitív) ép széllel került eltávolításra és pozitív sentinelnyirokcsomó-lelet miatt axillaris blokkdissectiót végeztünk. Az intraoperatív fagyasztásos szövettani vizsgálat a retroareolaris szövetet tumormentesnek igazolta. A mell rekonstrukcióját azonnali pótlással oldottuk meg. Endoszkóppal asszisztálva a teljes széles hátizmot forgattuk a mellkasra, majd modellálás után transcutan öltésekkel, a mell alsó áthajlási redőjének megfelelően, belülről rögzítettük. A mütéti idő 116 perc volt. A mütét után a mellkasi ejtődrént a második napon, a háti szívódrént a hatodik napon távolítottuk el. A mellen modellálókötést hagytunk egy hétig. A beteg az elért volumennel és formával teljesen elégedett volt.

\section{Módszer}

\section{Mütéti technika}

A beteget $2 \mathrm{~g}$ cefazolin-antibiózis és tromboprofilaxis mellett oldalfekvésben operáltuk enyhe anti-Trendelenburg-helyzetben. Az axillaris metszés íve alternálható, hossza körülbelül $8 \mathrm{~cm}$. Az axillaris preparálás és a thoracodorsalis ideg felkeresése és átvágása szabad szemmel történt, ahogy az izom cranialis részének subdermalis és submuscularis preparálása is. A caudalis részt ellátó intercostalis és lumbalis perforator ereket endoszkópos (5 mm-es kamera) vizualizációval kerestük fel és dissecáltuk (1. ábra). Az izom caudalis részének átvágása egy kis segédmetszésen át bevezetett LigaSure (Covidien, MN, Amerikai Egyesült Államok) eszközzel történt. Ezen a nyíláson át vezettük be a háti területre a szívódrént (16 Ch). A mellkasi területet az axillaris metszésből láttuk el. A latissimus izom mellkasra forgatása kapcsán kúp alakú formát modelláltunk a hátizom imbrikálásával és varratokkal (2. ábra).

\section{Megbeszélés}

A latissimus dorsi izomlebeny endoszkópos preparálásának fö előnye a nyitott technikához képes az, hogy a donorterületen nem marad vissza hosszú, sokszor nehezen vagy hypertrophiás heggel gyógyuló seb. A háton lévő heg ideális kialakulását bizonyos mütéti technikával, a háti bőrterület

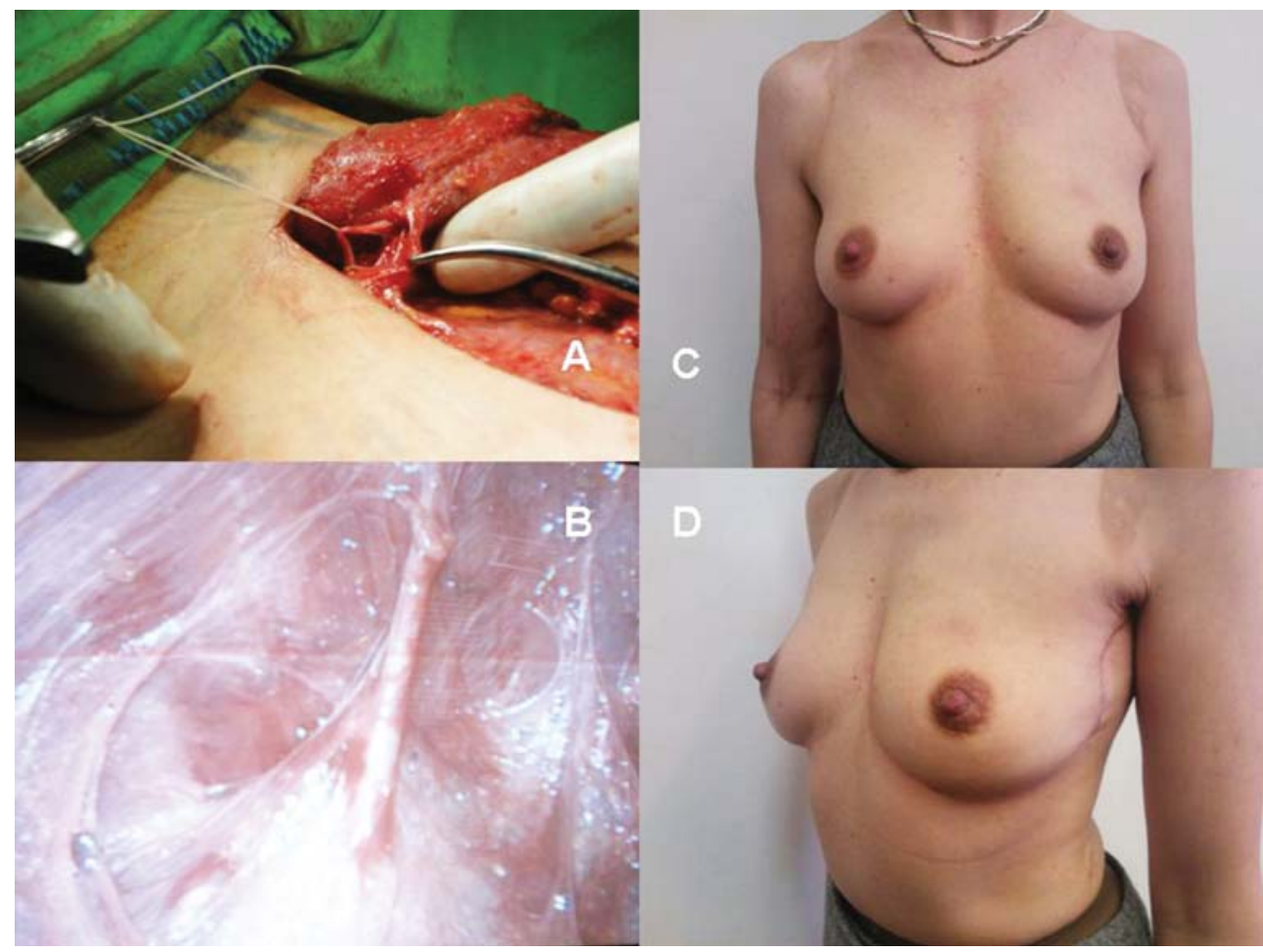

1. ábra. A) A kipreparált és később átvágott thoracodorsalis ideg. B) Az egyik distalis intercostalis perforator ér endoszkópos képe. C),D) Az operált beteg posztoperatív képei 


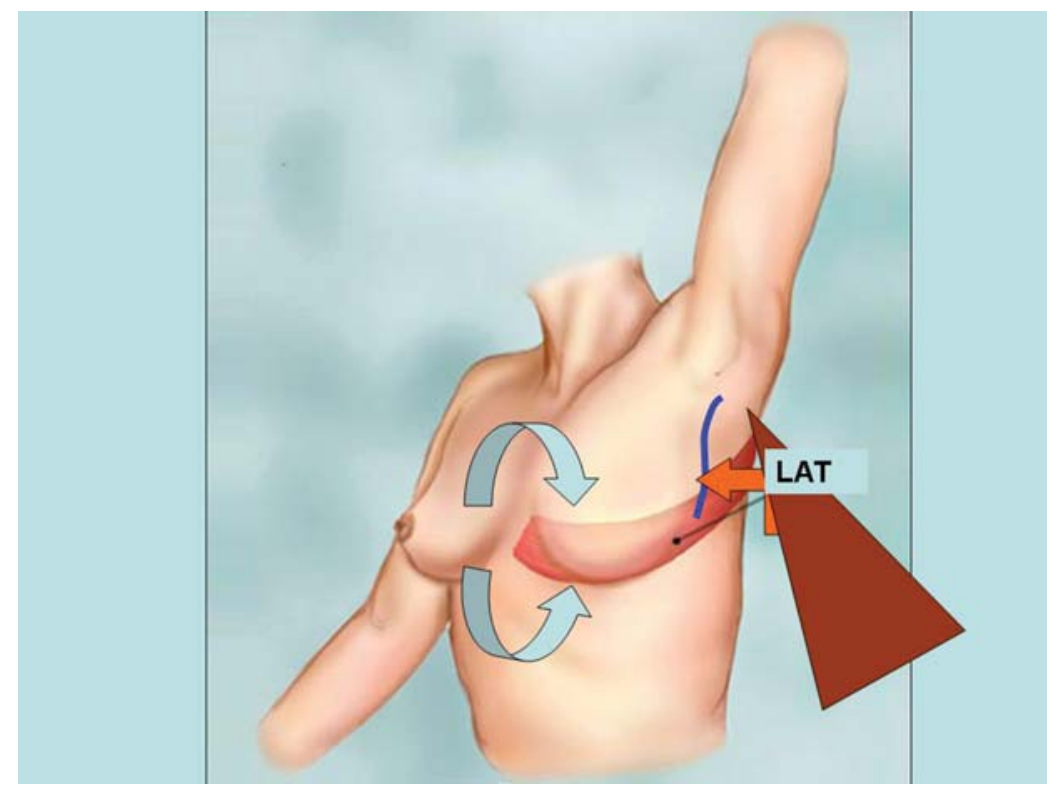

2. ábra. A sematikus ábra szemlélteti a műtétet, amely során az endoszkóppal kipreparált latissimus dorsi izmot (LAT) denerválás után a mellkasra forgatjuk (narancs nyíl) és ott modelláljuk az anatómiai igényeknek megfelelően (kék nyilak)

lehorgonyzó öltésekkel való fixációjával (quilting suture) javítani lehet. ${ }^{11}$ Vascones ugyan azt hangsúlyozza, hogy a heg jelenléte nem befolyásolja a beteg pszichés hozzáállását a rekonstrukcióhoz, mégis a legnagyobb esztétikai hátrány a sokszor kiszélesedő vagy a vastag irha miatt túlsarjadva gyógyuló háti heg. ${ }^{12}$ Az átlagosan $20 \mathrm{~cm}$ hosszúságú heg főként fiatal nőbetegeknél (fürdőruha, fehérnemü viselése) jelent pszichés problémát, ellentétben az endoszkópos technikánál visszamaradó, a hónalj felé vezethető, így részben elrejthető $6-10 \mathrm{~cm}$-es heggel szemben, és a háti terület „hegmentessége" miatt. ${ }^{13,14} \mathrm{Az}$ endoszkópos technika további előnye a gyorsabb felépülés, kevesebb ápolási igény, alacsonyabb morbiditás, kisebb posztoperatív fájdalom. A latissimus dorsi izom egy részének vagy egészének felhasználása általában nem okoz komolyabb mozgásbeli zavart, a betegek ugyanúgy sportolhatnak a mütét után. ${ }^{14}$

Az oldalfekvés, a mütét elött beadott Klein-oldat és/ vagy a mütéti terület $\mathrm{CO}_{2}$-inszufflálása megkönnyítheti a szélesebb és gyorsabb preparálást. Egyes szerzők a nyitott és az endoszkópos technika kombinálását javasolták. ${ }^{8,9}$ A LigaSure vágóeszköz használata a preparálásnál és az izom dissectiójánál elősegíti a kevesebb posztoperatív savó- vagy vérgyülem kialakulását és gyorsabb gyógyuláshoz vezet. ${ }^{15} \mathrm{Az}$ eszközt a hátsó axillaris vonalban vezetjük be, és a drenálás is innen történik. A mütéti idő a „learning curve" után jelentősen csökkenthető. Nakajima 168 esetben végzett endoszkópos latissimus dorsi preparálása után 50 perces időt ért el, ${ }^{5}$ míg Pomel 52 esetben végezve a technikát, 64 percről számolt be. ${ }^{8}$ Szimmetrizáció végett saját zsír átültetése is végezhető megfelelő technikájú zsírleszívás után. ${ }^{16}$ Legutóbb Selber nyolc páciensnél számolt be robottechnikával végzett latissimus dorsi preparálásról, ahol a robotsebészeti idő átlagosan 115 perc volt. ${ }^{17}$

\section{Összefoglalás}

A latissimus dorsi izomlebeny kiváló lehetőséget nyújt az emlörekonstrukció kapcsán azonnal behelyezett implantátumok alsó részének fedésére vagy kis volumenü emlők teljes rekonstrukciójára. Preparálása endoszkóppal megoldható, így biztosítva a jobb esztétikai eredményt és a magasabb betegelégedettséget a lelkileg mélyen érintett emlödaganatos betegek számára.

\section{Irodalomjegyzék}

${ }^{1}$ Fine NA, Orgill DP, Pribaz JJ: Early clinical experience in endoscopic-assisted muscle flap harvest. Ann Plast Surg 1994; 33: 465-472

${ }^{2}$ Ramakrishnan V, Southern SJ, Tzafetta R: Reconstruction of the high risk chest wall with endoscopic assisted latissimus dorsi harvest and expander placement. Ann Plast Surg 2000; 44: 250-258

${ }^{3}$ Serra-Renom JM, Serra-Mestre JM, Martinez L, D'Andrea $F$ : Endoscopic reconstruction of partial mastectomy defects using latissimus dorsi muscle flap whitout causing scars on the back. Aesth Plast Surg 2013; 37: 941-949

${ }^{4}$ Losken A, Schefer GT, Carlson GW, Jons GE, Styblo TM, Bostwick J III: Immediate endoscopic latissimus doersi flap risk of benefit in reconstructing partial mastectomy defects. Ann Plast Surg 2004; 53: 1-5

${ }^{5}$ Nakajima H, Fujiwara I, Mizuta N, Sakaguchi K, Ohashi $M$, Nishiyama $A$, et al.: Clinical outcomes of video-assisted skin sparing mastectomy for breast cancer and immediate reconstruction with latissimus dorsi muscle flap as breast-conserving therapy. World J Surg 2010; 34 : 2197-2203 
${ }^{6}$ Iglesias M, Gonzales-Chapa D: Endoscopic latissimus dorsi muscle flap for breast reconstruction after skin-sparing total mastectomy: report of 14 cases. Aesth Plast Surg 20134; 37: 719-727

${ }^{7}$ Nakajima H, Sakaguchi K, Mizuta N, Hachimine T, Ohe $S$, Sawai K: Video-assisted total glandectomy and immediate reconstruction for breast cancer. Biomed Pharmacother 2002; 56: 205-208

${ }^{8}$ Pomel C, Missana MC, Atallah D, Lasser P: Endoscopic muscular latissimus dorsi flap harvesting for immediate breast reconstruction after skin sparing mastectomy. Eur J Surg Oncol 2003; 29: 127-131

${ }^{9}$ Missina MC, Pomel C: Endoscopic latissimus dorsi flap harvesting. Am J Surg 2007; 194: 164-169

${ }^{10}$ Menke H, Erkens $M$, Olbrish RR: Evolving concepts in breast reconstruction with latissimus dorsi flaps: results and follow up of 121 consecutive patients. Ann Plast Surg 2001; 47: 107-114

${ }^{11}$ Hammond $C D$ : Latissimus dorsi flap breast reconstruction. Plast Reconstr Surg 2009; 124: 1055-1063

12 Vascones LO: Endoscopic latissimus dorsi flap harvesting. Am J Surg 2007; 194: 170-171
${ }^{13}$ Mátrai Z, Kunos Cs, Pukancsik D, Sávolt Á, Gulyás G, Kásler M: Endoszkóposan asszisztált latissimus dorsi izomlebeny alkalmazása a korszerü rekonstrukciós emlösebészetben. Orv Hetil 2014; 155: 106-113

${ }^{14}$ Lin $C H$, Wei FW, Levin LS, Chen MC: Donor-site morbidity comparison between endoscopically assisted and traditional harvest of free latissimus dorsi muscle flap. Plast Reconstr Surg 1999; 104: 1070-1078

${ }^{15}$ Güeven E, Basaran K, Yazar M, Özden BC, Kuvat SV, Aydin H: Electrothermal bipolar vessel sealer in endoscope-assisted latissimus dorsi flap harvesting. J Laparoendosc Adv Tech 2010; 20: 735-742

${ }^{16}$ Veber M, Guerin AM, Faure C, Delay E, Mojallal A: Breast reconstruction using muscle sparing latissimus dorsi flap and fat grafting. Ann Chir Plast Esthet 2012; 57: 366-372

${ }^{17}$ Selber JC, Baumann DP, Holsinger CF: Robotic harvest of the latissimus dorsi muscle: laboratory and clinical experience. J Reconst Microsurg 2012; 28: 457-464 